\title{
Determinants of Leadership and Organizational Culture in Implementing Business Strategies
}

\author{
Zainal Ilmi (D) ${ }^{1}$, Robiansyah (D) ${ }^{2}$, Michael Hadjaat ${ }^{3}$, Saida Zainurossalamia ZA (D) ${ }^{4}$, \\ Dio Caisar Darma $\otimes($ (D) 5 \\ Department of Management, Faculty of Economics and Business, Mulawarman University, Indonesia 1,2,3,4 \\ Department of Management, Sekolah Tinggi Ilmu Ekonomi Samarinda, Indonesia. ${ }^{5}$
}

\begin{abstract}
Leadership and organizational culture are essential factors in the sustainability of a business. The two things' strategy becomes a concept that is often used as a foundation by various companies in running their activities. This article aims to discuss the role of leadership and organizational culture in implementing business strategy. Societal, cultural norms influence leader attributes and behaviors. Leader attributes and actions can be affected by the organization's corporate environment, size, and technology. Leader attributes and behaviors can determine the organizational form and organizational culture, and vice versa.
\end{abstract}

\Corresponding author: diocaisar@stiesam.ac.id

\section{ARTICLE INFO}

Received: January 10, 2020

Revised: January 11, 2021

Accepted: January 12, 2021

Published: January 12, 2021

Keywords:

Diversity Management

OLDP

DLDP

Employees Performance

(cc) BY (C) 2021 The Author(s)

\section{Introduction}

Leadership has often been mentioned as one factor that determines the success of a company or organization, although many people interpret leadership differently. This can be understood because leadership is contextual, and people's conceptions of leadership also change from time to time (Darma et al., 2020; Pusriadi \& Darma, 2020). Leadership is not a new concept or phenomenon in work and business life, but its understanding varies. People's attention to the phenomenon of leadership also varies. Some people are interested in the phenomenon or practice of leadership by studying their leaders' characteristics and behavior in situations where leadership is practiced and lately interested in followers' perception of their leaders' behavior, personality, and features. Their behavior is no longer monolithically examined from followers' perceptions, and they learn which leader behaviors they prefer and which leader behaviors are required to enable sound decisionmaking (Zainurossalamia et al., 2020).

Preference for specific leader behavior has now become the concern of many studies in leadership, as reflected in the great attention of researchers to the sincerity of leader behavior in the eyes of followers. This behavior's sincerity will determine the magnitude of the impact of their behavior on attitudes and followers (Avolio, 2007; Wijayanti et al., 2020). 
One of the leadership assessment activities that have a broad impact is cross-cultural leadership research. In this cross-cultural study, there were some interesting findings of leadership that were initially underattention. One finding is the fact that the phenomenon of leadership is viewed differently in different cultural environments. Leadership is also seen as an essential factor in political and business life. In the cultural climate, certain countries tend to be skeptical of leaders and the concept of leadership. The historical experience causes them to worry that leaders who are honored will accumulate and abuse power. In these countries, rarely found public appreciation of leaders (House, 1992; GLOBE, 2012).

\section{Strategic Leadership and Operational Leadership}

Talking about leadership in organizations, organizational leadership includes activities in two fields. The first is strategic leadership, which aims to guide organizations related to changes that occur continuously. This requires that CEOs overcome differences, explain strategic goals, build organizations, and shape their culture that matches the opportunities and challenges of change. Second is operational leadership, to prepare management skills to overcome the turmoil of change. The meaning is to identify and provide managers at the operational level with operational leadership and vision like never before (Pearce \& Robinson, 2010; Maria et al., 2020; Faradila et al., 2020).

Table 1. Management processes and levels of management

\begin{tabular}{|c|c|c|c|}
\hline  & $\begin{array}{l}\text { - Attracting resources and } \\
\text { capabilities and developing the } \\
\text { business }\end{array}$ & $\begin{array}{l}\text { Developing operating managers } \\
\text { and supporting their activities } \\
\text { - Maintaining organizational } \\
\text { trust }\end{array}$ & $\begin{array}{l}\text { Providing institutional } \\
\text { leadership through shaping and } \\
\text { embedding corporate purpose } \\
\text { and challenging embedded } \\
\text { assumptions }\end{array}$ \\
\hline 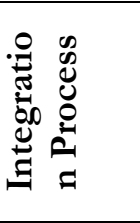 & $\begin{array}{l}\text { Managing operational } \\
\text { interdependencies and personal } \\
\text { networks }\end{array}$ & $\begin{array}{l}\text { Linking skills, knowledge, and } \\
\text { resource across units } \\
\text { - Reconciling short-term } \\
\text { performance and long-term } \\
\text { ambition }\end{array}$ & $\begin{array}{l}\text { We are creating a corporate } \\
\text { direction. } \\
\text { - Developing and nurturing } \\
\text { organizational values }\end{array}$ \\
\hline \multirow[t]{2}{*}{ 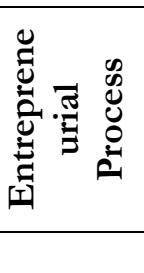 } & $\begin{array}{l}\text { Creating and pursuing } \\
\text { opportunities } \\
\text { - Managing continuous } \\
\text { performance improvement }\end{array}$ & $\begin{array}{l}\text { Reviewing, developing, and } \\
\text { supporting initiatives }\end{array}$ & $\begin{array}{l}\text { Establishing performance } \\
\text { standards }\end{array}$ \\
\hline & Lower Management & Middle Management & Top Management \\
\hline
\end{tabular}

Source: Bartlett \& Ghoshal (2001)

Several studies conducted by Bartlett \& Ghoshal (1997) on the most successful global companies in the last ten years concluded that combining the ability to respond flexibly to integration and innovation requires rethinking the management role and distribution of management roles mature companies (Maria et al., 2019).

The relationship between strategic leadership and operational leadership in organizations can be understood from thoughts on organizational leadership and management selection with the concept of management process and levels of management as presented in Table 1.

The entrepreneurial process is a decision-making process to capture opportunities and spread resources. Meanwhile, the integration process is the process of developing and distributing organizational capabilities. At the same time, the Renewal process is building organizational goals and possible changes. Usually, these three processes are the domain or authority of the top management or CEO. Bartlett \& Ghosal (1991), and Rugman's (2002) study proposes that these three processes need to be divided and distributed their roles to all three levels of management (top, middle, and lower management). 


\section{Relationship between Leadership and Childishness}

How important is the meaning of the relationship between the leader and his followers in the organization?. The relationship between leaders and those led at all levels of the organization determines whether or not all plans, activities are carried out and determines whether or not a career path takes place and the success or failure of a person. All individuals in the organization must be able to change and move well and adjust between two roles, namely as a leader and as being led (Chaleff, 1997; Kotler, 2005).

The form and nature of the actions and attitudes taken to comply with his leadership may be different from the actions and attitudes. However, the section chief and all his subordinates are followers of the leadership that exists and are applied in that section, where the leader is himself. This principle should also apply to officials who hold positions as branch heads, section heads, affairs heads, or even directors (Shaher \& Ali, 2020).

\section{The Concept of Organizational Culture}

The company needs to develop a work culture that is conducive to the emergence and growth of the potential and capabilities of its members that are used optimally, creatively, and responsibly if they want to develop into a company that not only meets the expectations of its shareholders but at the same time can also be the pride of its employees. For this reason, leadership practices are needed that can foster mutual trust and respect among fellow members of the company so that they can inspire members to work hard and work together synergistically to realize a shared goal. This leadership pattern can bring out and grow the best potential and human capabilities of the company members.

The company also needs managers who can show their leadership in efforts to develop a work climate characterized by an atmosphere of appreciation and high concern. Companies need to become business entities that can produce meaningful superior performance, the benefits of which can be felt by the company with all stakeholders fairly (Hartanto, 2009; Chayomchai, 2020).

\section{Assumptions of Transformational Work Culture}

Assumptions that underlie transformational work culture are fundamental because they relate to our beliefs about workers and issues related to the company's treatment of them. The basic premise is that workers are members of the company with great potential, workers are smart people, workers are respected corporate citizens, and workers need an environment conducive to hard work and intelligent cooperation (e.g., Pearce \& Robinson, 2010; Purwadi et al., 2020).

This basic assumption forms the mindset that underlies various management policies in employment and worker membership in the company. This assumption also determines how the desired organizational behavior is expected to become a habit and good manners of professional relations in the company environment. The development of structures, systems, and business and management practices also need to refer to this assumption.

This study itself was carried out using the basic assumptions put forward here as a theorizing foundation. Although this empirical evidence still needs to be re-tested with a larger sample that represents various fields of business activity, the results of this study indicate that the basic assumptions presented here should be considered as alternatives for use by business people in Indonesia who currently still apply many human concepts as resources in their structure, systems and management practices. This finding is also supported by research conducted in the GLOBE framework, which found that independent, individualistic, unique, and autonomous leadership proved unsuitable for efforts to realize shared interests (Gelfand et al., 2004). 


\section{Positive Psychology at Work}

People pay more attention to how human strength can be raised and developed together with effort, better understanding what factors can cause an individual or community to obtain a life worth fighting for (Seligman \& Czikszentmihalyi, 2000).

People will bring out their strength or potential in their efforts to achieve authentic happiness. But, not everyone is aware of this authentic happiness because they are used to living in conditions of powerlessness. They feel that whatever he does will have no impact on his life and future. This sense of helplessness arises due to his belief that his fate is not determined by himself. They are usually trapped by the assumption that this pessimistic explanation pattern is the only pattern used to explain a life phenomenon (Seligman, 1998; 2002).

View of life like this can extinguish the passion of life. To be able to arouse life's passion, people need to use an optimistic pattern of explanation. A more promising way of illustration usually places that failure can be avoided at other opportunities and success due to consistent good work and effort. Failure is seen not as a

consequence of others' actions or specific environmental conditions. Still, it is considered a result of work and effort that has not been done to the maximum.

\section{Corporate Culture and Work Culture}

Unlike the corporate culture, work culture is more describing the quality of human relationships and attitudes of a person towards each other and facing various workplace problems. Work culture is reflected in the habits of people interacting and communicating in the company environment, vertical relationships prevailing in the workplace, the enthusiasm of workers when facing their duties and work, the orientation of time when people live work life, and the values and norms that are held by workers at when they work and interact with colleagues (Mrówka \& Pindelski, 2011).

The discussion of culture in the corporate environment still creates confusion because each business and management expert defines the corporate culture and work culture differently. The shared perception of daily work practices should be considered as the core of organizational culture. Policies, decisions, and corporate management actions that are carried out consciously or unconsciously determine the cultural manifestations manifested in an organization or company environment (Hofstede, 1985; Hofstede \& Bond, 1984).

The leader factor indeed determines the shape of the company culture. The culture that prevails in the organizational environment can be developed, created, and changed by leaders who apply cultural principles to increase their organizations' effectiveness. Leaders who succeed in building a culture within the company usually show consistency in their behavior. That is, the culture that develops in an organizational environment develops naturally. Companies need this kind of leadership character to adjust to actual conditions and situations (Schein, 1992).

In the United States, during the 1980s, the focus of management's attention was on success and excellence. At the same time, workers still tended to be seen as factors of production that were expected to work according to the direction and direction of leaders and company regulations to realize that success. In the 1990s, corporate management in the United States showed its concern for workers when they realized that the company's success could be realized by placing people in the central place (Pfeffer \& Veiga, 1999).

Through the attitudes, hopes, and behavior of members, it is common for a company to be correctly regarded as someone who lives in its organization's culture. This is understandable because Dutch nationality comes from a more feminine cultural environment, seeing workers with higher care and empathy. These researchers try to understand how workers feel according to specific cultural dimensions. Even in subsequent studies, the same researcher tries to understand the gap between what is supposed and actual work practices (Hofstede et al., 1993). 
To understand why the development of work culture is so important, we need to understand what can be influenced by the work culture. In general, work culture is considered to be able to influence the focus of our attention at work, work behavior and professionalism of members of the company, things that are valued at work, perceptions about time, individuals, groups, society, and the natural environment, and the nature of the interaction between personally at work (Trompenaars \& Woolliams, 2003).

\section{Dimensions of Work Culture}

The dimensions of work culture that are most commonly used to describe cultural conditions in the workplace are those concerned with the vertical relationships found in the workplace, the nature of the cooperative association, the level of concern and consideration shown by people when they need to make a decision, the attitude of people in dealing with risk, and time orientation at work.

Based on what was just stated earlier, the idea to examine the culture in the company environment from five dimensions of work culture is viewed from the viewpoint of followers, namely: power distance, collectivism-individualism, femininity-masculinity, avoidance of uncertainty, and long-term orientation long. The five dimensions have been used as a reference by many researchers in corporate culture and work culture, and their validity is critically examined (Hofstede, 2001).

To understand this work culture dimension properly, we need to be careful when conducting studies on it because the study results can provide a distorted picture. The workforce's research needs to be carried out in a non-evaluative and empathic manner (emic study). By using an EMIC investigation, researchers place themselves amid the community being studied to feel the enthusiasm, hopes, and aspirations of those who are studied better. Researchers can also position themselves as outsiders when evaluating the culture of a community (time etc.). The use of ethical studies can cause misleading distortions and biases because researchers often have difficulty understanding the cultural aspects that are invisible and implied. Ethic studies that are often superficial should not be used in the development of work culture because the study results can be a source of new problems (Rehfeld \& Terstriep, 2016; 2017).

\section{The Proposition of Organizational Culture and Leadership}

In connection with thinking the concepts that have been presented previously, The Global Leadership and Organizational Behavior Effectiveness (GLOBE) conducted studies in 62 countries in the world. As can be seen in Figure 1 suggests an integrated theoretical model regarding leadership determinants and organizational culture.

Integration theory has 15 propositions, including norms of shared values (social and cultural) and tradition influence leaders' behavior. Leadership influences organizational forms, organizational culture, customs, cultural values of society, and practices also affect corporate culture and tradition. Also, organizational culture and traditions influence the behavior of leaders, social culture and traditions influence the process by which people contribute implicitly to the development of leadership theories, corporate culture and practices influence the methods by which people contribute to the development of approaches leadership implicitly, strategic organizational contingencies (organizational environment, size, and technology) influence the shape of the organization, organizational culture, and tradition, strategic organizational contingency (organizational environment, size, and technology) influences leadership characteristics and behaviors. 


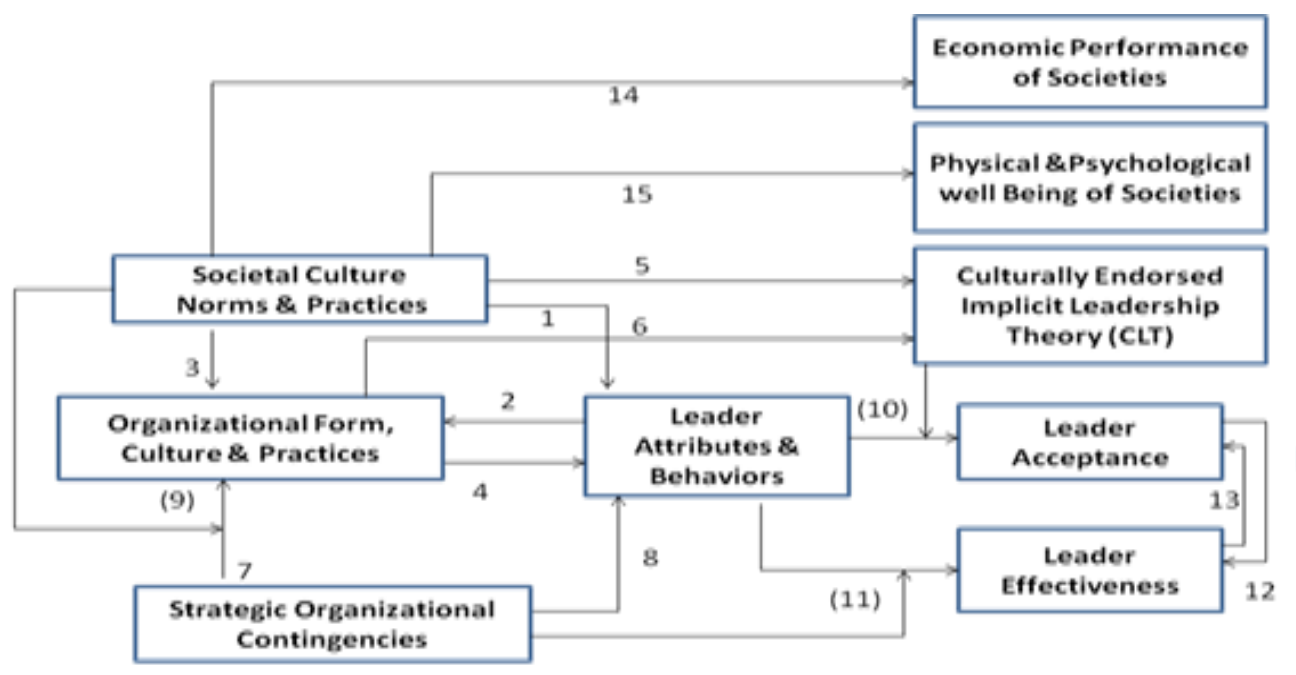

Figure1. The integrated theoretical model

Source: The GLOBE (2012)

The discussion of the relationship between the organization's strategic contingencies (organizational environment, technology, and size) and the traditions, organizational forms, and organizational culture will cause socio-cultural strength or pressure. Leaders are a function of the interaction between implicit theories of leadership, traits, and behavior. A leader's effectiveness is a function of the organization's strategic contingent interactions with leadership traits and behaviors. The acceptance of the leader by his followers facilitates the point of the leader. The significance of the leader over time will increase the approval of the leader. Cultural traditions in society are closely related to the economic competitiveness of a country. Socio-cultural practices also deal with physical health, individual well-being, and community members' psychological well-being (House et al., 2003).

\section{Conclusion}

The theoretical discussion of this thinking concludes some determinants of leadership and organizational culture in implementing business strategies. An effective leader can increase his followers 'acceptance of a leader, while his followers' approval of a leader will support his leadership effectiveness. Leaders' nature and behavior influence the acceptance of followers to a leader and determine the effectiveness of leadership. The personality and behavior of leaders are influenced by the norms of social-cultural values and traditions. The nature and behavior of leaders are influenced by the organizational environment, organizational size, and technology. The personality and behavior of leaders are influenced and affect the shape of the organization and organizational culture.

Funding: We are grateful for the specific funding support by the Faculty of Economics and Business, Mulawarman University and Sekolah Tinggi Ilmu Ekonomi Samarinda.

Acknowledgments: This work is purely the result of the discussion and ideas of the authors. Contribution from each author is divided into several phases including $45 \%$ for investigation, project administration, supervision, and writing - original draft by Dr. Zainal Ilmi and Dr. Saida Zainurossalamia ZA. Mr. Robiansyah focused on the resources section and paper validation (20\%). Then, the remaining 35\% is for visualization, writing - review, and editing by Mr. Michael Hadjaat and Mr. Dio Caisar Darma.

Conflicts of Interest: The authors declare no conflict of interest.

\section{References}


Avolio, B. J. (2007). Promoting More Integrative Strategies for Leadership Theory Building. American Psychologist, 62(1), 25-33. https://doi.org/10.1037/0003-066X.62.1.25

Bartlett, C. A., \& Ghoshal, S. (1991). Global strategic management: Impact on the new frontiers of strategy research. Strategic Management Journal, 12(1), 5-16. https://doi.org/10.1002/smj.4250120903

Bartlett, C. A., \& Ghoshal, S. (1997). The Myth of the Generic Manager: New Personal Competencies for New Management Roles. California Management Review, 40(1), 92-116. https:/ /doi.org/10.2307/41165924

Chayomchai, A. (2020). The moderating effect of generation on the relationship between commitment and performance: Evidence from human resource management model. Management Science Letters, 10(15), 3707-3716. https://doi.org/10.5267/j.msl.2020.6.022

Chaleff, I. (1997). The Courageous Follower: Standing Up to And for Our Leaders. NASSP Bulletin, 81(586), 119-119. https://doi.org/10.1177/019263659708158616

Darma, D. C., Purwadi, P., Sundari, I., Hakim, Y. P., \& Pusriadi, T. (2020). Job Characteristics, Individual Characteristics, Affective Commitments and Employee Performance. Research and Review: Human Resource and Labour Management, 10(1), 7-18. https://doi.org/10.5281/zenodo.3719117

Faradila, N., Heksarini, A., \& Darma, D. C. (2020). Antecedents That Affect Job Satisfaction and Employee Performance. Saudi Journal of Business and Management Studies, 5(6), 293-302. https://doi.org/10.36348/sjbms.2020.v05i06.001

Gelfand, M. J., Bhawuk, D. P., Nishii, L. H., \& Bechtold, D. J. (2004). Individualism and Collectivism. Dalam Culture, Leadership, and Organization: The GLOBE Study of 62 Societies. Thouands Oaks, California: Sage Publications.

Global Leadership and Organizational Behavior Effectiveness. (2012). Leader Effectiveness and Culture: The GLOBE Study. Retrieved from https://gdl29.files.wordpress.com/2014/03/globestudy.pdf [Accessed on June 18, 2020].

Hartanto, F. M. (2009). Paradigma Baru Manajemen Indonesia: Menciptakan Nilai dengan Bertumpu pada Kebajikan dan Potensi Insani. Bandung: Mizan.

House, R. J. (1999). Charismatic Leadership in Service-producing Organizations. International Journal of Service Industry Management, 3(2), 5-16. https://doi.org/10.1108/09564239210011944

House, R. J., Hanges, P. J., Javidan, M., Dorfman, P. W., \& Gupta, V. (2003). Culture, Leadership, and Organizations: The GLOBE Study of 62 Societies. Thousand Oaks: Sage Publications.

Hofstede, G. (1985). The interaction between national and organizational value systems. Journal of Management Studies, 22(4), 347-357. https://doi.org/10.1111/j.1467-6486.1985.tb00001.x

Hofstede, G. (2001). Culture's Consequences: Comparing Value, Behaviors, Institutions, and Organizations Across Nations. Thousand Oaks: Sage Publications.

Hofstede, G., \& Bond, M. H. (1984). Hofstede's Culture Dimensions: An Independent Validation Using Rokeach's Value Survey. Journal of Cross-Cultural Psychology, 15(4), 417-433. https://doi.org/10.1177/0022002184015004003

Hofstede, G., Bond, M. H., \& Luk, C. (1993). Individual Perceptions of Organizational Cultures: A Methodological Treatise on Levels of Analysis. Organization Studies, 14(4), 483-503. https://doi.org/10.1177/017084069301400402

Kotler, P. (2005). Principles of Marketing. New York: Pearson.

Maria, S., Darma, D. C., Amalia, S., Hakim, Y. P., \& Pusriadi, T. (2019). Readiness To Face Industry 4.0. International Journal of Scientific \& Technology Research, 8(9), 2363-2368.

Maria, S., Hakim, Y. P., \& Darma, D. C. (2020). Perceptions of Service Quality and Corporate Image Against Satisfaction and Customer Loyalty. KnE Social Sciences, 4(3), 9-25. https://doi.org/10.18502/kss.v4i3.6371

Mrówka, R., \& Pindelski, M. (2011). Dispersion of leadership in global organizations applying new types of organizational structures. Intellectual Economics, 5(3), 477-491.

Pearce, J. A., \& Robinson, R. B. (2010). Strategic management formulation, implementation and control (12th ed.). Boston, MA: McGraw-Hill. 
Pfeffer, J., \& Veiga, J. F. (1999). Putting people first for organizational success. Academy of Management Perspectives, 13(2), 37-48. https://doi.org/10.5465/ame.1999.1899547

Purwadi, P., Darma, D. C., Febrianti, W., \& Mirwansyah, D. (2020). Exploration of Leadership, Organizational Culture, Job Satisfaction, and Employee Performance. Technium Social Sciences Journal, 6(1), 116-130.

Pusriadi, T., \& Darma, D. C. (2020). Pengaruh talent management dan employee engagement terhadap employee capabilities: studi pada karyawan pt. Bintang wahana tata. Jurnal Riset Entrepreneurship, 3(1), 54-61. https://doi.org/10.30587/jre.v3i1.1317

Rehfeld, D., \& Terstriep, J. (2016). Coping with Social Innovation Dilemmas: An Exploratory Study of Middle Range Theory. Finance and Economy for Society: Integrating Sustainability, 11, 349-360. https://doi.org/10.1108/S2043-905920160000011014

Rehfeld, D., \& Terstriep, J. (2017). Theoretical Framework for the Economic Underpinnings of SI. SIMPACT Working Paper, 2017(1), 1-22. Gelsenkirchen: Institute for Work and Technology.

Rugman, A. M. (2002). The influence of "managing across borders" on the field of international management. Advances in Comparative International Management, 14, 37-56. https://doi.org/10.1016/S07477929(02)14031-5

Schein, E. H. (1992). Organizational Culture and Leadership (2nd ed.). California: Jossey-Bass.

Seligmen, M. E. (1998). Learned Optimism: How to Change Your Mind and Your Life. New York: The Free Press.

Seligmen, M. E. (2002). Authentic Happiness. New York: The Free Press.

Seligman, M. E., \& Csikszentmihalyi, M. (2000). Positive psychology: An introduction. American Psychologist, 55(1), 5-14. https://doi.org/10.1037/0003-066X.55.1.5

Shaher, A., \& Ali, K. (2020). The effect of entrepreneurial orientation and knowledge management on innovation performance: The mediation role of market orientation. Management Science Letters, 10(15), 3723-3734. https://doi.org/10.5267/j.msl.2020.6.020

Trompenaars, F., \& Woolliams, P. (2003). A new framework for managing change across cultures. Journal of Change Management, 3(4), 361-375. https://doi.org/10.1080/714023847

Wignyowiyoto, S. (2002). Leadership - Followership: Hubungan Dinamis Kepemimpinan - Keanakbuahan Sebagai Kunci Sukses Organisasi. Jakarta: PPM.

Wijayanti, T. C., Setini, M., Darma, D. C., Purwadi, P., \& Alka, P. R. (2020). Connectivity Continuous Improvement Program and Employee Performance. International Review of Management and Marketing, 10(1), 54-62. https:// doi.org/10.32479/irmm.9161

Zainurossalamia, S., Darma, D. C., Kasuma, J., Ratnasari, S. L., \& Tasențe, T. (2020). Apparatus performance as mediation of creativity and innovation towards the successful application of e-kelurahan. European Journal of Human Resource Management Studies, 4(2), 108-126. https://doi.org/10.5281/zenodo.3546289 